\title{
Infection by Serratia marcescens in porous orbital implant
}

\section{Infección por Serratia marcescens en implante orbitario poroso}

Lorena Fernández-Montalvo ${ }^{1 *}$, Nuria Ibáñez-Flores², Pilar Cifuentes-Canorea², and

Brenda C. Mendoza-García

${ }^{1}$ Ophthalmology Service, Hospital Universitario de San Juan de Alicante, Alicante; ${ }^{2}$ Orbit and oculoplastic surgery department of the Institut Català de la Retina, Barcelona. Spain

\begin{abstract}
Case report: We report a case of a patient who underwent left eye evisceration and porous polyethylene implant insertion after a traffic accident 3 years before. He developed recurrent implant exposition. Conjunctival swab culture showed growth of Serratia marcescens, a bacillus associated with nosocomial infections, especially in pediatric intensive care units, but rare in adults. Discussion: Implant infection should be suspected when there is persistent discharge and conjunctival dehiscence after implant insertion. Therefore, all patients with an implant exposure must undergo a culture for infection detection. When even appropriate antibiotics cannot control the infection, the implant must be removed.
\end{abstract}

Key words: Eye evisceration. Orbital implants. Complications. Infection. Anophthalmic socket. Serratia marcescens.

\section{Resumen}

Caso clínico: Se describe el caso de un paciente con antecedentes de evisceración en el ojo izquierdo e implante poroso de polietileno tras un accidente de tráfico tres años antes. Ha presentado exposiciones recurrentes del mismo. En el cultivo de las secreciones conjuntivales se aisló Serratia marcescens, un germen frecuentemente asociado a infecciones nosocomiales, sobre todo en unidades de cuidados intensivos pediátricas, y que es infrecuente en adultos. Discusión: La aparición de secreciones mucopurulentas en presencia de una dehiscencia conjuntival en un paciente con un implante orbitario debe alertarnos de una posible infección profunda del implante. Por ello, deberemos realizar cultivos para detectarla. Cuando el tratamiento antibiótico no puede controlar la infección, se requerirá la explantación del implante.

Palabras clave: Evisceración del ojo. Implantes orbitarios. Complicaciones. Infección. Cavidad anoftálmica. Serratia marcescens.

Correspondence:

*Lorena Fernández-Montalvo

University Hospital of S. Juan de Alicante

Ctra. Nacional, 332

Date of reception: 23-02-2017

03550 S. Juan de Alicante, Spain

E-mail: lorenafmontalvo@ gmail.com
Date of acceptance: 21-06-2017

DOI: 10.24875/RMOE.M19000076
Available online: XX-XX-2019 Rev Mex Oftalmol(Eng).2019;93(4):165-167

www.rmo.com.mx 2604-1731/@ 2019 Sociedad Mexicana de Oftalmología. Published by Permanyer México SA de CV. This is an Open Access article under the CC BY-NC-ND license (http://creativecommons.org/licenses/by-nc-nd/4.0/). 


\section{Introduction}

Currently, porous polyethylene (PP) orbital implants are widely used after enucleation or evisceration. Reported complications include secretions, persistent pain, conjunctival dehiscence, pyogenic granuloma, exposure and infection of the implant ${ }^{1}$. Although the latter is rare, it is the most serious complication because it usually leads to implant removal ${ }^{2}$.

\section{Clinical case}

A 48-year-old male patient underwent an emergency evisceration in another center, with a $20-\mathrm{mm}$ PP implant placed after a diagnosis of left ruptured globe secondary to a road traffic accident three years ago. Currently, he seeks medical attention due to pain and discomfort with his implant since surgery, that have not improved despite several implant changes. Upon interview, the patient reports that after the road traffic accident he was admitted to the intensive care unit (ICU) for three weeks. Ophthalmological examination showed a central conjunctival dehiscence with a $6 \times 7 \mathrm{~mm}$ exposure of the PP implant with no signs of infection (Fig. 1).

Given the findings on physical examination, we decided to perform an orbital cavity reconstruction with implant milling and a pericranial graft to cover the conjunctival defect. A culture of the secretions from the exposed implant was negative. The initial postoperative evolution was slow but favorable, achieving complete conjunctivalization of the graft in four months. The patient attended periodic follow-ups up to a year later, when he went to the emergency room referring mucopurulent secretions and pain in the left eye. On examination, a central conjunctival dehiscence was observed with exposure of the implant and whitish secretions (Fig. 2). It was decided to perform a new culture and antibiogram of the conjunctival exudate, which was positive for Serratia marcescens. We initiated treatment with ciprofloxacin $750 \mathrm{mg}$ every 12 hours, omeprazole $20 \mathrm{mg}$ every 24 hours and topical $0.5 \%$ moxifloxacin hydrochloride every 2 hours, based on the antibiogram. One week later the implant was removed and the culture was repeated, confirming colonization by $S$. marcescens. Since it required an important volume, it remained two weeks without an implant and with antibiotic treatment based on antibiogram until the infection was considered cured. Afterwards, he presented a marked improvement, so a preoperative dose of intravenous ceftazidime was prescribed, and the

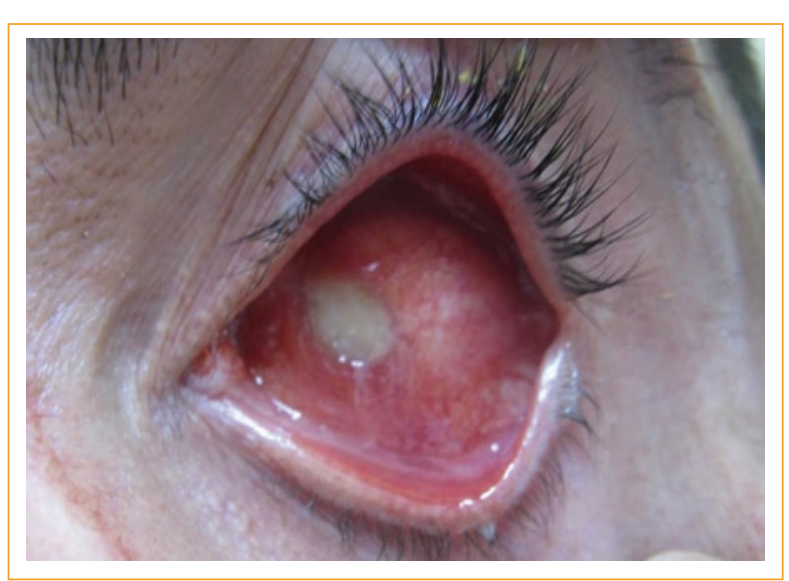

Figure 1. Central conjunctival dehiscence $(6 \times 7 \mathrm{~mm})$ with exposure of the Medpor implant.

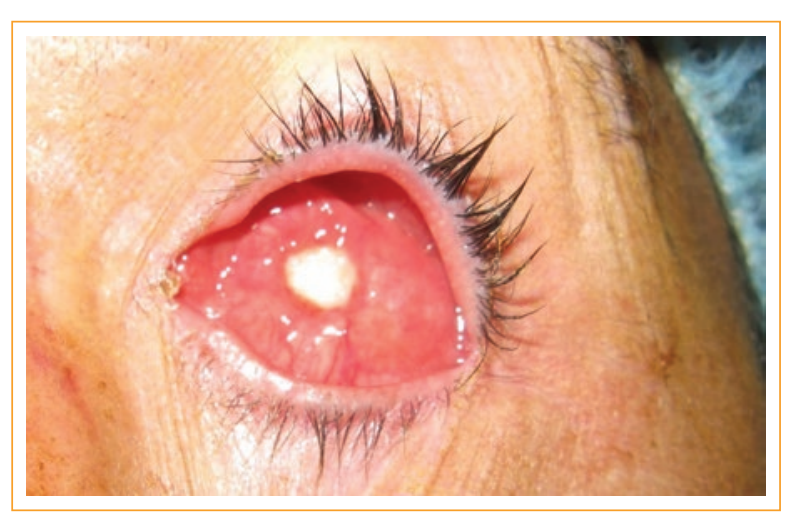

Figure 2. Exposure of the implant one year after reconstruction of the orbital cavity with a pericranial graft.

cavity was reconstructed. For this surgery, we used a gluteal dermal fat implant that was placed on a $20-\mathrm{mm}$ PP orbital implant with injection of subconjunctival $100 \mathrm{mg} / 0.5 \mathrm{~mL}$ ceftazidime and tissue injection of $50 \mathrm{mg} / \mathrm{mL}$ enhanced ceftazidime. After three years of follow-up, he remains asymptomatic, with good functional results and good adaptation to the implant.

\section{Discussion}

Porous polyethylene implants were used as orbital implants for the first time by Dresner in $1991^{3}$. They are made from a synthetic material (high density PP), with a hydrophobic and negatively charged surface, which acts as a protective layer that inhibits bacterial adherence. It has pores with a size of between 150-400 microns (mean 200 microns) that allow the integration 
of the fibrovascular orbital tissue of the receptor and implant fixation, thereby decreasing the risk of infection and extrusion ${ }^{4}$.

The most frequent complication associated with their use is implant exposure ${ }^{1,5-8}$. Implant infection is a rare but feared complication due to its severity. The germs enter when the implant is placed or postoperatively through conjunctival dehiscence. The germs inside the implant multiply and migrate to the surface, where they cause inflammation and conjunctival dehiscence. This can act as a gateway, so the problem is perpetuated. Jung, et al., in a series of 314 cases with PP orbital implants, reported three cases of infection unresponsive to medical treatment. Cultures reported Staphylococcus aureus in two cases and Staphylococcus epidermidis in the other case ${ }^{6}$. You et al., in a series of patients with orbital hydroxyapatite implant infection by $S$. aureus, $S$. epidermidis, $\alpha$-hemolytic streptococci and peptostreptococci, reported lack of response to medical treatment. The only case that could be controlled with antibiotic therapy had a PP implant ${ }^{8}$. In our case, the causative agent of the implant infection was $S$. marcescens, a Gram-negative bacillus often associated with severe nosocomial infections in the ICU, especially in pediatric patients ${ }^{9}$. Although endophthalmitis due to S. marcescens is rare, it has been related to post-trabeculectomy blebitis, phacoemulsification, penetrating keratoplasty, exposure of scleral cerclage, exposure of a glaucoma drainage device, keratoprosthesis and post-insertion of an alloplastic orbital implant due to orbital floor fracture ${ }^{10,11}$. Seyhan et al. presented a case of intranasal implantation of a PP infected by $S$. marcescens seven years after its insertion in a patient with Hashimoto's disease that required removal ${ }^{12}$. However, we have not found any published cases of orbital implant infection secondary to evisceration. The infection may have occurred during admission to the ICU before the vascularization of the implant was fully developed (it may take several months), so the germs were compartmentalized in the implant in sites that are difficult to reach for antibiotics and host immune cells. This would explain that the patient referred discomfort since the post- evisceration period, as well as a state of chronic conjunctival inflammation that did not improve with topical treatment or with implant replacement.

\section{Conclusion}

Implant infection should be suspected when there is persistent discharge and conjunctival dehiscence after implant insertion. Therefore, all patients with implant exposure must undergo a culture for infection detection. When even appropriate antibiotics cannot control the infection, the implant must be removed.

\section{Ethical disclosures}

Protection of human and animal subjects. The authors declare that no experiments were performed on humans or animals for this study.

Confidentiality of data. The authors declare that they have followed the protocols of their work center on the publication of patient data.

Right to privacy and informed consent. The authors have obtained the written informed consent of the patients or subjects mentioned in the article. The corresponding author is in possession of this document.

\section{Funding}

No funding.

\section{Conflicts of interest}

There is no conflict of interest of the researchers in this study.

\section{References}

1. Jordan DR, Bawazeer A. Experience with 120 synthetic hydroxyapatite implants (FCl3). Ophthal Plast Reconstr Surg. 2001:17:184-90.

2. Jordan DR, Brownstein S, Faraji H. Clinicopathologic analysis of 15 explanted hydroxyapatite implants. Ophtalm Plastic Reconstructive Surg. 2004:20:285-90

3. Karesh JW, Dresner SC. High-density porous polyethylene (Medpor) as a successful anophthalmic socket implant. Ophthalmology. 1994; 101:1688-95

4. Lee S, Maronian N, Most SP, Whipple ME, McCulloch TM, Stanley RB, et al. Porous high-density polyethylene for orbital reconstruction. Arch Otolaryngol Head Neck Surg. 2005;131:446-50.

5. Lee JH, Yang SW, Choi WV. Clinical outcome and complications of Medpor orbital implant. J Korean Ophthalmol Soc. 2001;42:933-8.

6. Jung SK, Cho WK, Paik JS, Yang SW. Long-term surgical outcomes of porous polyethylene orbital implants: a review of 314 cases. $\mathrm{Br} \mathrm{J}$ Ophthalmol. 2012;96(4):494-8.

7. Alwitry A, West S, King J, Foss AJ, Abercrombie LC. Long-term follow-up of porous polyethylene spherical implants after enucleation and evisceration. Ophthal Plast Reconstr Surg. 2007;23(1)11-5.

8. You Jr, Seo JH, Kim YH, Choi WC. Six cases of bacterial infection in porous orbital implants. Jpn J Ophthalmol. 2003;47(5):512-8.

9. Voelz A, Müller A, Gillen J, Le C, Dresbach T, Engekhart S, et al. Outbreaks of Serratia marcescens in neonatal and pediatric intensive care units: clinical aspects, risk factors and management. Int J Hyg Environm Health. 2010;213:79-87.

10. Equi RA, Green WR. Endogenous Serratia marcescens endophthalmitis with dark hypopyon: a case report and review. Surv Ophthalmol. 2001;46:259-68

11. Sridhar J, Kuriyan AE, Flynn HW, Smiddy W, Venincasa VD, Miller D. Endophthalmitis caused by Serratia marcescens. Clinica features, antibiotic susceptibilities, and treatment outcomes. Retina. 2015;35:1095-100.

12. Seyhan $T$, Borman $H$, Deniz M. Kocer E. Intranasal porous polyethylene implant extrusion 7 years after insertion in a patient with Hashimoto disease. J Craniofac Surg. 2009;20(1):73-4. 